\title{
Problematika Orang Tua dalam Menjalankan Perannya sebagai Guru Bagi Anak Usia Dini
}

\author{
Jenri Ambarita ${ }^{1 凶}$ Ester Yuniati $^{2}$, Ica Purnamasari ${ }^{3}$ \\ Pendidikan Agama Kristen, Institut Agama Kristen Negeri Ambon, Indonesia(1), Pendidikan \\ Agama Kristen, Institut Agama Kristen Negeri Manado, Indonesia(2), Pendidikan Luar \\ Sekolah, Universitas Negeri Malang, Indonesia(3) \\ DOI: $10.31004 /$ obsesi.v6i3.1358
}

\begin{abstract}
Abstrak
Wabah virus corona telah membawa dampak terhadap perubahan kebijakan pemerintah dalam bidang pendidikan yang menerapkan pembelajaran jarak jauh tidak terkecuali dengan Pendidikan Anak Usia Dini. Orang tua memegang peran yang sangat sentral untuk mendampingi anak belajar terlebih anak usia dini. Artikel ini bertujuan untuk mengetahui problematika yang dihadapi oleh orang tua dalam menjalankan perannya sebagai guru. Penelitian ini menggunakan pendekatan kualitatif dengan jenis penelitian studi kasus melalui wawancara pada 10 orang tua anak usia dini yang bersekolah di PAUD Melisa. Hasil penelitian ini menunjukkan bahwa permasalahan utama yang dihadapi oleh orang tua adalah minimnya keahlian mereka dalam mengajar, sulitnya memotivasi anak, lingkungan yang kurang kondusif dan keterbatasan waktu. Namun, latar belakang pendidikan orang tua tidak mempengaruhi kemampuan mereka memahami materi anak usia dini karena bagi mereka materi anak usia dini belum bisa dikategorikan sulit. Demikian halnya dengan masalah waktu, sekalipun menjadi kendala bagi sebagian orang tua akan tetapi pendampingan anak dalam belajar tidak terabaikan.
\end{abstract}

Kata Kunci: problematika orang tua; peran sebagai guru; anak usia dini.

\begin{abstract}
The corona virus outbreak has had an impact on changes in government policies in the field of education that implement distance learning, including Early Childhood Education. Parents play a very central role in assisting children to learn, especially early childhood. This article aims to determine the problems faced by parents in carrying out their role as teachers. This study used a qualitative approach with a case study research type through interviews with 10 parents of early childhood who attended PAUD Melisa. The results of this study indicate that the main problems faced by parents are their lack of expertise in teaching, difficulty in motivating children, an unfavorable environment and limited time. However, the educational background of parents does not affect their ability to understand early childhood material because for them the material for early childhood cannot be categorized as difficult. Likewise with the problem of time, even though it is an obstacle for some parents, the assistance of children in learning is not neglected.
\end{abstract}

Keywords: parental problems; role as teacher; early childhood.

Copyright (c) 2021 Jenri Ambarita, et al.

$\triangle$ Corresponding author:

Email Address : jenriambarita7@gmail.com(Ambon, Maluku, Indonesia)

Received 13 May 2021, Accepted 31 May 2021, Published 30 September 2021

Jurnal Obsesi: Jurnal Pendidikan Anak Usia Dini, 6(3) 2022 | 1819 


\section{PENDAHULUAN}

Pendidikan menjadi bagian penting yang tidak akan pernah bisa dipisahkan dari kehidupan manusia, baik pendidikan formal ataupun non formal. Pendidikan Indonesia memiliki tujuan mulia, yaitu untuk mencerdaskan kehidupan bangsa (Furqon Arbianto et al., 2019; Kosim, 2011; Nida Uliatunida, 2020). Seseorang yang lahir ke dunia akan mengalami yang namanya pembelajaran hingga dia tumbuh dewasa (Fauzi, 2020). Pendidikan yang diterima oleh seorang anak, akan sangat mempengaruhi kehidupannya di masa yang akan datang (Jailani, 2014).

Pembelajaran anak bukan sepenuhnya menjadi tanggung jawab dari sekolah, melainkan menjadi bagian dari keluarga. Keluarga menjadi tempat yang paling pertama dan utama bagi seseorang untuk mendapatkan pendidikan (Irma et al., 2019). Pernyataan ini juga sejalan dengan pendapat Syahran yang mengatakan bahwa, keluarga merupakan lembaga pendidikan pertama bagi seorang anak (Jailani, 2014). Oleh karena itu, keluarga diharapkan bisa memberi waktu dan tenaga untuk memperhatikan kehidupan anggota keluarganya, memenuhi kebutuhannya baik kebutuhan fisik-biologis maupun kebutuhan psikologisnya (Samsinar, 2019). Hal ini bertujuan agar seorang anak atau anggota keluarga merasa nyaman berada di tengah-tengah keluarga. Ketenangan, kenyamanan, kerukunan atau keharmonisan di tengah-tengah keluarga menjadi sangat penting untuk dibangun bersama. Noffiyanti mengatakan bahwa, orang tua harus mampu menciptakan dan mewujudkan keharmonisan dalam keluarga (Noffiyanti, 2020).

Anak yang berada di dalam keluarga yang tidak seimbang, anak yang kurang mendapatkan perhatian, jarang terlibat dalam interaksi di dalam rumah, anak yang kurang mendapatkan tanggung jawab dari orang tua, sangat berdampak terhadap pribadi anak yang menjadi lebih keras, hilang percaya diri, emosi dan merasa kurang nyaman di dalam pergaulannya sebagaimana temuan penelitian Siti dan Retnaningsih dalam (Rahmatullah, 2017).Keluarga yang harmonis ditandai dengan adanya hubungan baik antara suami dengan istri, orang tua dengan anggota keluarga yang lainnya(Rahmatullah, 2017).

Banyak orang tua yang menyerahkan secara penuh tugas mendidik anak kepada pihak kedua yaitu sekolah sebagaimana dikatakan oleh Rosdiana dalam (Agustien Lilawati, 2021). Orang tua harus menyadari ketika anak memasuki usia sekolah, bukan berarti orang tua lepas tanggung jawab dari pendidikan seorang anak, karena seorang anak hanya akan berada di sekolah dalam kurun waktu 6 jam dan selebihnya berada di tengah-tengah keluarga. Karena itu, pendidikan menjadi tanggungjawab bersama baik orang tua, sekolah dan masyarakat. Selain itu, kesibukan orang tua dalam beraktifitas di luar rumah juga seolah memaksa orang tua untuk menyerahkan anaknya kepada pembantu atau tempat penitipan anak (Supsiloani et al., 2016).

Orang tua yang memiliki anak dalam usia sekolah seolah terlepas dari beban sebagai pendamping akademik bagi anak. Selama ini, orang tua hanya menjadi pendamping dalam pendidikan keagamaan, penanaman nilai-nilai kebaikan dalam keluarga dan hal-hal yang sangat dasar bagi seorang anak (Ramadhani et al., 2020). Namun, saat ini pergeseran peran banyak terjadi dalam dunia pendidikan tidak terkecuali dengan dunia pendidikan tingkat anak usia dini. Pendampingan akademik yang selama ini diserahkan kepada guru di sekolah, harus beralih kepada orang tua sebagai pelaksana tugas guru saat belajar di rumah (Agustien Lilawati, 2021; Ayuni et al., 2020).

Belajar dari rumah (BDR) menjadi kebijakan yang diberlakukan oleh negara-negara yang terdampak covid-19, tidak terkecuali dengan Indonesia (Kemendikbud, 2019; Pujiasih \& Bantul, 2020). Selain untuk memutus mata rantai penyebaran virus corona, kebijakan ini juga bertujuan untuk memenuhi hak belajar anak di masa pandemi dan juga memastikan kesehatan para peserta didik (Kemendikbud, 2020a). Kebijakan ini semakin diperkuat dengan dikeluarkannya surat edaran no.15 tahun 2020 oleh Kemendikbud. 
Belajar dari rumah menjadi budaya belajar baru yang diberlakukan di Indonesia dan di beberapa negara yang terdampak oleh virus corona (Pakpahan \& Fitriani, 2020). Pembelajaran dengan memanfaatkan teknologi dan akses internet menjadi solusi alternatif yang banyak diberlakukan oleh lembaga dan berbagai kegiatan seperti pembelajaran mulai dari tingkat perguruan tinggi sampai pendidikan anak usia dini, kegiatan seminar, pelatihan dan yang lainnya (Ambarita et al., 2021; Darmalaksana et al., 2020; Purwasih et al., 2020; Sadikin \& Hamidah, 2020; Sulata \& Hakim, 2020; Wicaksana, 2020).

Pembelajaran dengan mengandalkan teknologi sudah diterapkan oleh beberapa lembaga pendidikan yang ada di Indonesia sejak lama, salah satunya adalah pembelajaran yang diterapkan oleh Universitas Terbuka (Darmayanti et al., 2007). Namun, pembelajaran dengan memanfaatkan kemajuan teknologi dan akses internet ini masih menjadi budaya baru bagi banyak lembaga pendidikan lainnya, sehingga butuh waktu untuk beradaptasi.

Berbagai permasalahan terjadi dalam pembelajaran jarak jauh yang sedang diberlakukan, mulai dari ketidaksiapan sarana-prasarana, bahkan keterbatasan pemahaman TIK baik dari pihak guru, siswa maupun orang tua. Akses internet yang kurang lancar banyak dikeluhkan oleh pendidik dan peserta didik yang melaksanakan pembelajaran daring. Tidak hanya di wilayah Indonesia, kesenjangan internet ini juga masih terjadi di berbagai daerah negara Asia tenggara lainnya (Jalli, 2020).

Pembelajaran online menuntut semua pihak untuk melek dengan teknologi, karena pembelajaran online bisa berjalan dengan baik jika didukung oleh sarana prasarana yang cukup seperti komputer, android, laptop (Ambarita et al., 2021; Pakpahan \& Fitriani, 2020). Beberapa tahun terakhir ini, Andorid sudah sangat familiar dikalangan masyarakat bahkan sampai anak usia dini sudah banyak yang menggunakannya. Andorid menjadi salah satu media yang sangat efektif dan bisa dimanfaatkan untuk mendukung pembelajaran jarak jauh (Korucu \& Alkan, 2011).

Pendidikan anak usia dini menjadi salah satu sorotan dalam penerapan pembelajaran online yang diterapkan pada masa pandemi covid-19. Pendampingan ekstra dari pihak keluarga sangat dibutuhkan saat mendampingi anak dalam melakukan aktifitas belajar di rumah. Guru sebagai pelaksana pembelajaran yang selama ini dilaksanakan, harus beralih kepada orang tua sedangkan guru hanya sebagai perancang pembelajaran (Ayuni et al., 2020). Sebagai orang tua yang memiliki tugas baru sebagai pendamping akademik tentunya menuntut orang tua memiliki pemahaman bahkan keterampilan dalam menjalankan peran barunya sebagai guru PAUD (Dewi \& Suryana, 2020).

Dalam menjalankan peran barunya sebagai orang tua dan sekaligus sebagai guru bukanlah hal yang mudah, orang tua harus bisa beradaptasi dan bahkan membiasakan diri. Setiap orang tua memiliki kesibukan atau pekerjaan, latar belakang pendidikan yang berbedabeda yang tentunya berdampak pada cara mereka dalam menjalankan perannya sebagai orang tua dan sebagai guru bagi anaknya di rumah.

Dalam sebuah penelitian yang telah dilakukan oleh Agustien Lilawati, menemukan bahwa peran orang tua dalam pembelajaran di masa pandemi covid-19 semakin bertambah, mulai dari peran segagai pendamping akademik dan sebagai motivator bagi seorang anak (Agustien Lilawati, 2021). Penulis melihat bahwa temuan penelitian ini sangat penting untuk dikembangkan atau dilanjutkan, karena tulisan ini belum sampai membahas problematika yang dihadapi oleh orang tua anak usia dini dalam menjalankan peran barunya sebagai pendamping akademik.

Sejak kebijakan pembelajaran dari rumah diterapkan dalam dunia pendidikan di Indonesia, banyak permasalahan yang terjadi dari pihak guru, siswa ataupun orang tua siswa. Pembelajaran jarak jauh atau belajar dari rumah membawa perubahan atau pergeseran peran dalam pembelajaran. Guru tidak lagi bisa mendampingi anak usia dini secara langsung, sehingga dituntut peran aktif dari orang tua untuk mendampingi peserta didik dalam belajar (Agustien Lilawati, 2021; Pininta, 2020). 
Berdasarkan latar belakang di atas penelitian ini bertujuan untuk mendeskripsikan : 1) Cara orang tua dalam menjalankan perannya sebagai guru dalam mendampingi anak belajar dari rumah; 2) Problematika orang tua/wali anak usia dini dalam menjalankan perannya sebagai guru, ditinjau dari sisi pekerjaan orang tua dan kualifikasi pendidikan orang tua; 3 ) Upaya yang dilakukan oleh orang tua dalam mengatasi permasalahan yang dihadapi. Berdasarkan tujuan penelitian ini, maka akan diperoleh pengetahuan tentang berbagai problematika yang dihadapi oleh orang tua sebagai guru dan upaya-upaya dalam mengatasinya.

\section{METODOLOGI}

Metodologi yang digunakan dalam tulisan ini didasari pada tujuan dari penelitian yang akan dilakukan, yaitu: 1) Untuk mengetahui permasalahan yang dihadapi oleh orang tua dalam menjalankan perannya sebagai seorang guru; dan 2) Untuk mengetahui upayaupaya yang dilakukan oleh orang tua dalam menyelesaikan permasalahan yang dihadapi. Jika ditilik dari tujuan penelitian tersebut, maka peneliti menggunakan pendekatan kualitatif dengan jenis penelitian studi kasus. Moleong mengatakan bahwa metodologi kualitatif merupakan prosedur penelitian utuk mengumpulkan data dalam bentuk deskriptif atau prosedur politik (Lexi \& M.A., 2010). Penelitian ini dilakukan di rumah orang tua peserta didik selama dua bulan, yaitu Maret - April 2021. Gambar 1 merupakan gambaran tahapantahapan penelitian yang telah dilakukan.

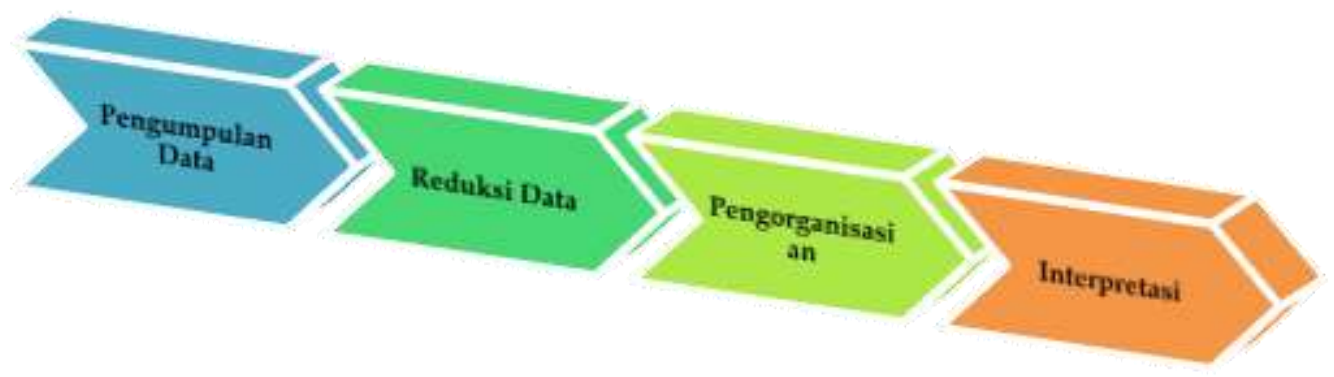

Gambar 1. Gambaran tahapan kegiatan penelitian

Tabel 1. Gambaran orang tua peserta didik sebagai informan dalam penelitian

\begin{tabular}{|c|c|c|c|c|}
\hline No & \multicolumn{2}{|c|}{ Respon (Ayah-Ibu) } & Tamatan & Pekerjaan \\
\hline \multirow{2}{*}{1} & & Bapak Samuel Sahusiwa & SMA & Wiraswasta \\
\hline & R1 & Jolanda Leuwol & S1 & Pegawai Swasta \\
\hline \multirow{2}{*}{2} & \multirow{2}{*}{$\mathrm{R} 2$} & Bapak Daud J Samadar & SMA & PNS \\
\hline & & Orpa Samadara & SMA & Ibu Rumah Tangga \\
\hline \multirow{2}{*}{3} & \multirow{2}{*}{$\mathrm{R} 3$} & Bapak Harold P Marantika & SMA & Tentara \\
\hline & & Noni T Salukh & S1 Kep & Perawat \\
\hline \multirow{2}{*}{4} & \multirow{2}{*}{ R4 } & Bapak Galvin F Soplantila & SMA & Polri \\
\hline & & Rosyan E Sakalessy & S1 & Guru \\
\hline \multirow{2}{*}{5} & \multirow{2}{*}{ R5 } & Frits B Tuhusula & SMA & Polri \\
\hline & & Welna Tehupuring & $\mathrm{S} 1$ & Perawat \\
\hline \multirow{2}{*}{6} & \multirow{2}{*}{ R6 } & - & - & - \\
\hline & & Bertha Tumansery & SMA & CS \\
\hline \multirow{2}{*}{7} & \multirow{2}{*}{ R7 } & Jefri Sahusiwa & SMA & Buru Bangunan \\
\hline & & Herlin Balun & SMA & Ibu Rumah Tangga \\
\hline \multirow{2}{*}{8} & \multirow{2}{*}{$\mathrm{R} 8$} & Ruslan Mokodompit & SMA & Petani \\
\hline & & Nenci Sahusiwa & SMA & Ibu Rumah Tangga \\
\hline \multirow{2}{*}{9} & \multirow{2}{*}{ R9 } & Friton Yohanis & SMA & Petani \\
\hline & & Eti Yohanis & SMA & Ibu Rumah Tangga \\
\hline \multirow{2}{*}{10} & \multirow{2}{*}{$\mathrm{R} 10$} & Charles Nanuru & SMP & Sopir \\
\hline & & Yermina Kakisina & SMP & Ibu Rumah Tangga \\
\hline
\end{tabular}


Dalam pengumpulan data yang dibutuhkan, peneliti terlibat langsung secara aktif di lapangan dan menjadi instrument utama. Karena kehadiran peneliti menjadi tolok ukur pemahaman terhadap beberapa kasus. Teknik pengumpulan data utama dalam penelitian ini adalah wawancara yang kemudian akan dianalisis dengan menggunakan tematik(Heriyanto, 2018). Analisis tematik merupakan analisis data kualitatif yang banyak digunakan dengan tahapan reduksi data, pengorganisasian dan interpretasi.Penelitian ini dilakukan di tempat tinggal orang tua peserta didik dari PAUD Melisa di Nusaniwe Airlouw Kota Ambon dengan 10 keluarga sebagai informan. Selengkapnya dapat dilihat pada tabel 1.

\section{HASIL DAN PEMBAHASAN}

Berbagai temuan penelitian terdahulu telah banyak mengungkap akan bahaya (Ilpaj \& Nurwati, 2020) dan penyebarannya virus corona yang begitu cepat (Dewi, D.S., Setyani, J. \& Yulyanti, 2021) membawa dampak yang sangat besar dalam tatanan kehidupan masyarakat. Budaya pembelajaran konvensional yang selama ini menjadi ciri pendidikan Indonesia harus mengalami pergeseran dan secara tidak langsung virus corona ini seolah memaksa pendidikan kita untuk segera mengimplementasikan pendidikan abad 21 sebagai jawaban atas tuntutan era industri 4.0. Pembelajaran Jarak Jauh yang diterapkan pada masa pandemi covid-19 membutuhkan kerjasama yang baik antara guru, siswa dan orang tua. Orang tua memiliki peran yang sangat penting dalam pembelajaran dari rumah, bahkan peran orang tua semakin meluas sebagaimana hasil temuan penelitian yang dilakukan oleh (Agustien Lilawati, 2021).

Dalam wawancara penulis dengan para informan sebagai langkah untuk mengumpulkan data yang akurat, peneliti membagi tiga kategori pertanyaan, yaitu: 1) Bagaimana orang tua menjalankan perannya sebagai guru dalam pembelajaran pada masa pandemi; 2) Apa saja kendala-kendala yang dialami oleh orang tua saat mendampingi anak belajar; dan 3) Upaya apa yang dilakukan oleh orang tua dalam menyelesaikan segala kendala yang dialami.

Pembelajaran dari rumah yang diberlakukan oleh pemerintah menuntut kerjasama yang baik antara guru, siswa dan para orang tua (Khadijah \& Gusman, 2020). Selama ini, banyak orang tua yang menyerahkan sepenuhnya masalah pendidikan anak kepada sekolah dan sebagian orang tua menjadi kurang peduli dengan pendidikan anak karena sudah percaya kepada sekolah (Hatimah, 2016). Namun, situasi saat ini mengharuskan pembelajaran dilaksanakan dari rumah dan orang tua dituntut untuk bisa mendampingi anak (Purwanto et al., 2017). Pembelajaran dari rumah menjadi budaya belajar baru bagi orang tua yang tentunya butuh waktu untuk beradaptasi. Penelitian-penelitian sebelumnya telah mengemukakan kendala-kendala yang dihadapi oleh banyak orang tua saat mendampingi anak dalam belajar. Secara umum kendala yang dihadapi oleh banyak orang tua tidak jauh beda dengan yang lainnya seperti kurangnya pemahaman materi oleh orang tua, kesulitan orang tua dalam menumbuhkan minat belajar anak, tidak memiliki cukup waktu untuk mendampingi anak karena harus bekerja, orang tua tidak sabar dalam mendampingi anak saat belajar dirumah, kesulitan orang tua dalam mengoperasikan gadget, dan kendala terkait jangkauan layanan internet (Wardani \& Ayriza, 2020).

Lebih lanjut mereka mengatakan bahwa anak usia dini sangat berbeda dengan jenjang pendidikan yang lainnya (SD,SMP,SMA/K). Anak Usia Dini (AUD) yang identik dengan dunia permainan (Bastian et al., 2019) masih sangat butuh pengawasan dari orang dewasa, dengan demikian tidak bisa dibiarkan belajar atau bermain sendiri.

\section{Cara Orang Tua Menjalankan Perannya Sebagai Guru dalam Pembelajaran di Masa Pandemi}

Peran orang tua sangat dalam pembelajaran di masa pandemi sangatlah penting karena situasi yang belum memungkinkan untuk melakukan pembelajaran dari rumah. Hal ini juga senada dengan pernyataan yang disampaikan oleh Kepala Badan Penelitian dan 
Pengembangan dan Perbukuan (Kabalitbang dan Perbukuan) Totok Suprayitno yang mengatakan bahwa peran orang tua sangatlah sentral dan hampir $90 \%$ orang tua mendampingi anak saat belajar dari rumah pada semua jenjang (Kemendikbud, 2020b). Bagaimana cara orang tua menjalankan perannya sebagai guru di rumah akan sangat mempengaruhi kenyamanan anak dalam proses pembelajaran.

Dalam tahap pertama, peneliti mengumpulkan data mengenai cara orang tua menjalankan perannya sebagai guru. Dalam menjalankan perannya sebagai guru, orang tua cukup berperan aktif dalam memperhatikan belajar anak seperti memperhatikan jadwal belajar yang sudah diberikan oleh guru, memperhatikan materi yang diberikan guru, menjelaskan materi kepada anak dan mendampingi anak dalam mengerjakan soal-soal yang sudah diberikan oleh guru. Hal ini juga tidak jauh berbeda dengan temuan penelitian (Agustien Lilawati, 2021) yang mengatakan bahwa orangtua mendampingi anak belajar dengan kasih sayang, pemberian materi pembelajaran disiapkan guru di terapkan kepada anak melalui orangtua harus sebisa mungkin bersabar sesuai dengan tahapan pembelajaran yang benar, contoh dalam kegiatan membaca anak didampingin orangtua yang memberikan materi selanjutnya ditirukan oleh anak.

Berikut ini adalah beberapa kutipan wawancara dari para orang tua AUD sebagai informan dalam penelitian ini.

... Kami selaku orang tua selalu berperan aktif saat anak belajar di rumah, namun terkadang faktor lingkungan, yang mempengaruhi anak-anak sehingga tidak fokus pada saat belajar...(kutipan wawancara dengan Keluarga Bapak Samuel (wirausaha) dan ibu Jolanda Leuwol yang bekerja sebagai seorang pegawai swasta)

... Kami selaku orang tua selalu berperan aktif saat belajar di rumah dan selalu berusaha untuk memperhatikan jam belajar anak, walaupun itu kami lakukan setelah pulang tugas...(kutipan wawancara dengan Kel. Bapak Frits yang bekerja sebagai seorang Polisi dan ibu Welna Tehupuring sebagai perawat)

... Kami selaku orang tua selalu berperan aktif saat belajar di rumah dan memperhatikan jam belajar anak. Selesai melakukan aktifitas di rumah, saya sering melihat materi yang diberikan dari guru/sekolah, saya mengulang kembali walau hanya belajar dari rumah ke rumah, kadang sulit bagi kami, tapi kami harus berusaha demi anak-anak kami, karna kami bukan besic guru, yang mampu menghadapi anak-anak dengan segala macam karakter...(Kutipan wawancara dengan Keluarga Bapak Jefri yang bekerja sebagai buruh bangunan dan ibu Herlina Balun sebagai ibu rumah tangga)

...Kami selaku orang tua selalu berperan aktif saat belajar di rumah dengan memperhatikan jam belajar anak, mengajar anak dan memberikan soal-soal sesuai dengan apa yang telah diberikan oleh guru kepada mereka...(Kutipan wawancara dengan Kel. Bapak Ruslan yang bekerja sebagai Petani dan ibu Nenci Sahusiwa sebagai ibu rumah tangga)

...Peran dan perhatian orang tua memanglah sangat penting bagi putra-putri nya, utamnya bertujuan untuk anak-tetap memperoleh pendidikan dengan baik, walaupun di tengah kondisi seperti ini, adanya covid-19 menuntut peran orang tua, secara maksimal dalam pendidikan anak. Saya selaku orang tua anak usia dini selalu memperhatikan waktu belajar anak dan memperhatikan tugas-tugas yang telah diberikan oleh guru..(Kutipan wawancara dengan Kel. Bapak Friton yang bekerja sebagai seorang Petani dan ibu eti Yohanis sebagai ibu rumah tangga)

Dalam wawancara yang penulis lakukan, orang tua mengatakan bahwa mereka cukup aktif dalam memperhatikan pembelajaran anak di rumah. Lebih lanjut, latar belakang pendidikan orang tua tidak menjadi hambatan bagi mereka dalam mendampingi anak belajar dari rumah.Selama mendampingi anak belajar, orang tua mengatakan bahwa materi pelajaran anak usia dini belum bisa dikatakan sulit. Oleh sebab itu, mereka tidak kesulitan untuk memahami materi atau tugas yang diberikan oleh guru.

Selain tamatan terakhir para orang tua, masalah kesibukan kerja juga tidak menjadi kendala utama bagi orang tua untuk mendampingi anak belajar dari rumah. Sebagaimana dikatakan bahwa bagi orang tua yang keduanya aktif bekerja di luar rumah tetap 
memperhatikan belajar anak dan selalu berusaha mendampingi anak belajar setelah pulang dari tempat kerja walaupun tidak sesuai jadwal belajar. Lebih lanjut, orang tua mengatakan bahwa orang tua menyerahkan pendampingan belajar kepada pembantu tetapi orang tua tetap mengontrol lewat sambungan telepon atau video call. Selain itu orang tua tetap komunikasi dengan guru di sekolah sehingga orang tua tetap bisa mengetahui perkembangan pembelajaran anak.

\section{Problematika orang tua dalam menjalankan perannya sebagai guru}

Untuk menjadi guru bagi anak usia dini bukanlah hal yang mudah, tentunya butuh banyak pemahaman dan keterampilan untuk bisa menjadi guru yang baik bagi mereka.Guru TK/PAUD Al-Azhar Kota Bekasi Nini mengakui bahwa mengajar anak-anak PAUD pada masa pandemi lebih sulit dibandingkan siswa SD dan SMP. Sebab, anak usia dini perkembangan otaknya berada di rentang paling pesat, sehingga stimulasi yang tepat sangat dibutuhkan (Radarbekasi.id, 2020). Oleh sebab itu, orang tua yang banyak menjalankan peran sebagai pendamping akademik bagi anak dituntut untuk beradaptasi agar bisa menjadi guru yang diharapkan oleh siswa. Berbagai permasalahan terjadi selama kebijakan BDR diberlakukan oleh pemerintah, demikian halnya dengan permasalahan yang dihadapi orang tua anak usia dini yang ada di PAUD Melisa sangat variatif. Berikut ini merupakan problematika orang tua anak usia dini dalam menjalankan perannya sebagai guru, yaitu:

Problematika yang pertama adalah minimnya keahlian mengajar yang dimiliki oleh orang tua. Seorang guru dituntut menjadi seorang pendidik kreatif yang memiliki banyak strategi, metode dalam menyampaikan materi pembelajaran. Hal ini bertujuan agar para peserta didik merasa tertarik untuk mengikuti pembelajaran. Hal yang senada juga disampaikan oleh Abdul Muis Joenady yang mengatakan bahwa, keterbatasan sarana prasaran akan teratasi oleh kreatifitas yang dimiliki oleh seorang guru dalam mengajar (Muis, 2019). Guru yang tidak memiliki banyak kreatifitas dalam mengajar anak, tentunya membuat para peserta didik sulit untuk bisa fokus dan bahkan akan sangat cepat bosan.Kondisi inilah yang sebenarnya banyak dikeluhkan oleh para orang tua saat mendampingi anak dalam belajar.

Berikut ini peneliti lampirkan beberapa kutipan hasil wawancara dengan orang tua peserta didik.

... Kendala sering kami alamipada saat belajar di rumah yaitu: cara mengajar anak usia dini. Ini menjadi masasalah utama karena kami tidak memiliki keahlian sebagai seorang guru, bahkan anak-anak tidak mengikuti perintah yang terkadang membuat kami sebagai orang tua emosi dan marah...(kutipan wawancara dengan Keluarga Bapak Samuel tamatan SMA (wirausaha) dan ibu Jolanda Leuwol tamatan S1 yang bekerja sebagai seorang pegawai swasta)

... Kendala yang sering kami alami saat mendampingi anak belajar adalah : kurang pemahaman atau keterampilan yang kami miliki tentang cara mengajar anak PAUD, sehingga kurang mampu menghadapi anak bahkan sering emosi. Selain itu, kesibukan pekerjaan membuat perhatian akan pembelajaran anak juga terabaiakn... (Kutipan wawancara dengan keluarga Bapak Harold yang berprofesi sebagai seorang tentara dan ibu Noni yang bekerja sebagai seorang perawat)

... Selama pembelajaran di rumah saya sering mendapat kendala yaitu anak saya sering mengatakn kalau saya bukan seorang guru PAUD, klo anak saya punya ibu guru, yang harus mengajari nya...(Kutipan wawancara dengan keluarga Bapak Galvin tamat SMA yang bekerja sebagai seorang Polisi dan Ibu Rosyan tamatan S1 yang bekerja sebagai seorang guru SMA)

Dari hasil wawancara ditemukan bahwa tamatan terakhir yang dimiliki oleh orang tua tidak menjamin kemampuannya untuk menjadi seorang guru yang baik bagi anak usia dini. Hal ini ditunjukkan dari kutipan dari hasil wawancara yang menunjukkan bahwa orang tua yang tamat SMA, S1, bahkan orang tua yang berprofesi sebagai guru SMA mengatakan kesulitan mereka untuk menjadi guru yang baik bagi anak usia dini. Untuk menjadi guru anak usia dini harus memiliki keterampilan kusus, sedangkan orang tua tidak pernah mendapatkan 
pelatihan atau bahkan mendapatkan pendampingan bagaimana cara untuk menjadi guru yang baik bagi anak usia dini. Hal ini senada dengan pernyataan Muhdi yang mengatakan bahwa salah satu penyebab orang tua kesulitan saat mendampingi anak belajar dari rumah adalah minimnya pengalaman dan belum mendapatkan pendampingan (Nurkolis \& Muhdi, 2020).

Dari hasil wawancara, peneliti tidak menemukan orang tua yang mengatakan bahwa materi anak usia dini sulit untuk dipahami. Dengan kata lain, orang tua mengetahui dan bisa memahami materi yang telah diberikan oleh guru. Akan tetapi, orang tua merasa kesulitan untuk menyampaikannya kepada anak karena minim teknik/strategi, sehingga seringkali orang tua memaksa dan penuh dengan emosi saat mengajar anak. Temuan ini sedikit berbeda dengan hasil penelitian Anita yang mengatakan bahwa pemahaman meteri oleh orang tua dalam mendampingi anak belajar di rumah menjadi kendala dalam pelaksanaannya (Wardani \& Ayriza, 2020).

Problematika yang kedua adalah memotivasi anak untuk belajar. Dari hasil wawancara dengan orang tua anak usia dini, mereka mengatakan merasa kesulitan untuk menumbuhkan motivasi anak untuk mau belajar. Motivasi dan niat belajar yang dimiliki seseorang akan sangat mempengaruhi keberlangsungan proses pembelajaran. Untuk memotivasi atau menumbuhkan niat belajar anak usia dini dalam belajar bukanlah hal yang mudah. Karena butuh kreatifitas atau berbagai cara dan kesabaran yang ekstra untuk menghadapi anak usia dini. Dalam temuan penelitiannya Amna Emda mengatakan bahwa Motivasi memiliki kedudukan yang penting dalam mencapai tujuan pembelajaran yang telah ditetapkan. Munculnya motivasi tidak semata-mata dari diri siswa sendiri tetapi guru harus melibatkan diri untuk memotivasi belajar siswa (Emda, 2018).

Keterbatasan kemampuan orang tua dalam memotivasi anak untuk belajar, membuat orang tua terkesan berfokus kepada penyampaian materi kepada anak atau mendampingi mengerjakan tugas tanpa memperhatikan kesiapan anak untuk belajar. Kesulitan untuk menumbuhkan motivasi belajar anak membuat anak memberontak, bosan, bahkan menganggap bahwa orang tuanya tidak layak untuk menjadi guru bagi mereka. Hal ini membuat orang tua tersulut emosi dan marah kepada anak saat belajar dari rumah. Oleh sebab itu, orang tua harus memiliki strategi dalam menumnuhkan motivasi anak dalam belajar agar pembelajaran bisa berjalan dengan baik (Nurul Fadlilah, 2021). Berikut ini beberapa kutipan wawancara penulis dengan orang tua anak usia dini sebagai informan.

...Kendala yang di hadapi, yaitu kadang anak sering melawan kami selaku orang tua, mereka tidak paham apa yang kami berikan kepada mereka, dan kadang saya sering emosi, karena mereka sering bilang nanti besok belajar dengan ibu guru. Bukan dengan mama...(Kutipan wawancara keluarga Bapak Jefri dan ibu Herlin)

...anak-anak tidak mengikuti perintah yang terkadang membuat kami sebagai orang tua emosi dan marah...(kutipan wawancara dengan Keluarga Bapak Samuel tamatan SMA (wirausaha) dan ibu Jolanda Leuwol tamatan S1 yang bekerja sebagai seorang pegawai swasta)

Problematika yang ketiga adalah faktor lingkungan belajar yang kurang kondusif. Suasana rumah memiliki peran penting dalam proses pembelajaran anak di rumah. Rumah yang nyaman, kondusif, harmonis tentunya membuat seisi rumah merasa betah bakan berlama-lama untuk tinggal di rumah. Hal ini juga didukung oleh pernyataan Abdul Muis Joenady yang mengatakan bahwa rumah yang nyaman membuat penghuni atau orang yang datang tidak ingin beranjak meninggalkannya (Muis, 2019). Menciptakan suasana nyaman di rumah adalah tugas semua penghuni yang ada di rumah tersebut, namun peran orang tua sangatlah sentral.

Pembelajaran dari rumah menimbulkan banyak polemik yang terjadi antara anak dengan orang tua, anak dengan anak atau bahkan suami dan istri. Orang tua harus memperlengkapi sarana-prasarana belajar anak dan bahkan harus mendampingi anak saat belajar. Jika orang tua yang memiliki anak usia sekolah lebih dari satu orang, tentunya akan 
menjadi kendala atau membut orang tua kerepotan. Orang tua tentunya akan bingung mendampingi yang mana, selain itu juga orang tua harus memikirkan tempat yang kondusif agar anak bisa belajar dengan tenang dan baik. Jumrawarsi mengatakan bahwa kelas yang kondusif membuat para peserta didik tidak mudah jenuh, membuat anak terhindar dari kelelahan psikis dan juga terciptanya kelas yang kondusif akan memberikan motivasi dan ketahanan dalam belajar (Jumrawarsi \& Suhaili, 2020).

Berikut ini kutipan dari wawancara penulis dengan orang tua anak usia dini sebagai informan dalam penelitian ini.

... Kami sebagai ibu rumah tangga, sangat merasa dibuat pusing dengan tingkah anak-anak. Kami memiliki lima orang anak, yang no 1 sudah tingkat SMP, no 2 masih SD, no 2 masih jenjang PAUD dan 2 orang lagi belum sekolah. Saya sebagai orang tua merasa kewalahan dan kesulitan dalam membagi waktu ketika ketiga anak saya harus belajar bersamaan bingung mau harus mendampingi anak yang mana, karena semua butuh pendampingan saat belajar. Ketika saat mendampingi anak PAUD belajar dari rumah, anak sering kali melawan dan tidak bisa diarahkan dan terkadang juga diganggu oleh adek2nya yang kecil membuat saya sebagai orang tua sering emosi, marah dan bahkan pasrah....(Kutipan wawancara bersama keluarga Bapak Daud yang berprofesi sebagai seorang PNS dan Ibu Orpa sebagai ibu rumah tangga.

Problematika yang terakhir adalah keterbatasan waktu yang dimiliki oleh orang tua dalam mendampingi anak belajar dari rumah. Peran orang tua sangatlah penting untuk mendampingi anak belajar dari rumah. Anak usia dini belum bisa dilepas secara mandiri untuk belajar atau bahkan bermain, oleh sebab itu dibutuhkan peran penting orang tua dalam belajar. Orang tua merupakan guru pertama sejak kelahiran anak dan peran itu akan tetap melekat bagi anak-anaknya. Oleh sebab itu, orang tua harus selalu mengupayakan kebersamaan dengan anak untuk membimbing atau mendampingi anak sebagaimana dikatakan oleh Irhamnna dalam (Wardani \& Ayriza, 2020). Pernyataan ini juga didukung oleh penyataan Totok Suprayitno yang mengatakan bahwa orang tua memengang peranan yang sangat sentral dalam pembelajaran dari rumah (Kemendikbud, 2020b). Namun, faktor pekerjaan yang menghasruskan orang tua untuk tetap bekerja di luar rumah menjadi salah satu kendala bagi orang tua untuk memiliki waktu yang cukup bersama anak dalam pembelajaran di masa pandemi.

...Kendala yang di hadapi, yaitu kami harus menjadi guru bagi anak-anak, sedangkan waktu kami terbatas, sehingga tugas kami di berikan kepada pengasuh anak yang selalu mendampinggi anak-anak saya. Namun, kami sebagai orang tua tetap memantau melalui sambungan telepn dan komuniksi dengan guru...(Kutipan wawancara dengan keluarga Bapak Frits dan ibu Welna) ... Peran kami sebagai orang tua kuramg maximal. Karena keterbatasan waktu yang kami miliki. Kami suami istri bekerja di luar rumah setiap harinya, sehingga mengurangi waktu kami untuk bersama anak...(Kutipan wawancara dengan Kel. Bapak Harold Pier Marantika sebagai seorang tentara dan Noni.T.Salukh yang bekerja sebagai seorang perawat)

Temuan penelitian ini juga senada dengan penelitian yang dilakukan oleh Anita Wardani dan Ayriza yang mengatakan bahwa sebagian orang tua tidak memiliki cukup waktu untuk menemani anak belajar dirumah karena harus bekerja menjadi masalah lain dimasa pandemic Covid-19 ini. (Wardani \& Ayriza, 2020)

\section{Upaya Orang Tua dalam Menyelesaikan Permasalahan yang Dihadapi}

Banyak masalah atau kendala yang dihadapi oleh orang tua dalam pembelajaran dari rumah yang diberlakukan di masa pandemi, namun orang tua harus bisa keluar dari segala permasalahan tersebut. Orang tua tidak bisa berpasrah diri dengan segala keadaan, karena sesungguhnya tidak ada masalah di dalam masalah yang terselersaikan dengan baik. Wardani mengatakan bahwa segala permasalahan-permasalahan dalam pembelajaran harus tetap di evaluasi agar orang tua semakin bisa meminimalisir permasalahan yang ada (Wardani \& 
Ayriza, 2020). Dengan demikian anak-anak dapat memperoleh pembelajaran yang lebih baik saat belajar dari rumah.

Ada beberapa tindakan orang tua sebagai upaya mengatasi segala permasalahan pembelajaran dimasa pandemi, yang pertama adalah membangun kerjasama antara suami dan istri. Kerjasama suami dan istri sangat dibutuhkan dalam membangun rumah tangga yang harmonis. Demikian dengan situasi pandemi yang belum berakhir, mengharuskan pembelajaran masih dilaksanakan dari rumah masing-masing. Oleh sebab itu, orang tua memiliki peran yang meluas dari sebelumnya, karena orang tua juga harus bisa berperan sebagai seorang guru bagi anak di rumah. Tentunya, menjalankan peran baru ini bukan hal yang mudah untuk dilakukan sebab itu dibutuhkan kerjasama antara suami dan istri. Satu pekerjaan jika dikerjakan bersama-sama akan terasa lebih ringan (Suadnyana, 2018), demikian juga tugas mendampingi anak belajar akan menjadi lebih ringan jika dikerjakan bersama-sama oleh suami dan istri. Hal senada juga disampaikan oleh Ginanjar yang mengatakan bahwa orang tua harus bersinergi untuk memperhatikan pendidikan anak, terutama dalam pembelajaran di masa pandemi covid-19 (Ginanjar, 2017).

Berikut ini adalah kutipan wawancara peneliti dengan orang tua anak usia dini sebagai informan dalam penelitian.

... Kerjasama kami sebagai suami istri dalam mendampingi anak cukup baik, walau kami selalu sibuk dengan pekerjaan kami masing -masing, terkadang peran suami yang lebih banyak dengan anak, karena saya bekerja, kadang pulang anak sudah tidur, tapi pagi sebelum pergi kerja saya selalu mencuri waktu, karna kadang pembelajaran BDR, kadang tatap muka, yang terjadi pada PAUD MELISSA... (kutipan wawancara dengan Kel. Bapak Samuel yang bekerja sebagai wirausaha dan ibu Jolanda Leuwol yang bekerja sebagai Pegawai Swasta)

Yang kedua adalah berusaha memahami situasi dan kondisi keluarga. Permasalahan sering timbul ketika satu dengan yang lain tidak bisa saling memahami. Ketika guru tidak bisa memahami siswa dalam belajar, tentunya akan menimbulkan konflik dalam pembelajaran dan sebaliknya. Suami dan istri sebagai nakhoda rumah tangga tidak hanya dituntut untuk memiliki arah tujuan yang sama, lebih dari itu suami istri harus bisa saling memahami satu dengan yang lain. Ibu Orpa mengatakan bahwa dia harus mendampingi anak belajar dari rumah karena suaminya bekerja di luar rumah dari pagi sampai sore bahkan terkadang malam.

...Karena suami saya pergi kerja dari pagi pulang sore, kadang malam, sehingga kadang waktu belajardengan anak tidak ada, semua di limpahkan kepada saya sebagai seorang istri... (kutipan wawancara dengan Kel. Bapak Daud (PNS) dan Ibu Orpa yang bekerja sebagai ibu rumah tangga)

Hal yang tidak jauh berbeda juga disampaikan oleh ibu Welna yang mengatakan bahwa suaminya yang bertugas di Papua membuat mereka harus berjauhan. Dengan demikian, ibu Welna harus mendampingi aktivitas anak-anaknya seorang diri. Namun, ibu Welna mengatakan bahwa dia sebagai seorang istri sudah siap akan hal itu dan bisa memahami kondisi mereka.

...Karna tugas dan tanggung jawab pekerjaan yang membuat kami terpisah, ayah dari anak-anak di daerah papua, sehingga waktu komunikasi dengan ayah anak-anak tergantung jaringan. Kadang ayah anak-anak rindu melihat anak-anak belajar, pas dapat sinyal hanya videocall untuk melihat saja. Jadi saya sebagai istri harus bisa memahami situasi keluarga kami.. (kutipan wawancara dengan kel. Bapak Frits seorang polisi dan ibu Welna Tehupuring yang bekerja sebagai seorang perawat)

Selain itu, hal yang tidak boleh dilupakan juga adalah bekerjasama antara satu dengan yang lain dengan segala kelebihan dan kekurangan yang dimiliki. Agar pekerjaan tidak terkendala, suami istri harus bekerjasama dalam mendampingi anak saat belajar ataupun saat 
bermain. Suami yang memiliki kesempatan hendaknya mendampingi anak saat belajar atau bermain, demikian sebaliknya.

...Kerjasama antar suami istri sangat baik, kami saling menutupi tugas dan tunggung jawab selaku orang tua. Ketika suami berada di rumah, kadangkala kami bergantian untuk mendampingi anak untuk bermain ataupun belajar...(Kutipan wawancara dengan Kel. Bapak Jefri yang bekerja sebagai buruh bangunan dan ibu Herlina Balun yang bekerja sebagai ibu rumah tangga)

...Kerjasama yang kami bangun antara suami istri sangat baik, dalam pendampingan anak di rumah. Walapun waktu suami terbatas berada di rumah, tetapi kami selalu bisa bekerjasama. Saya yang hanya sebagai ibu rumah tangga lebih banyak mendampingi anak belajar, sedangkan suami selalu mendampingi anak hanya ketika berada di rumah ...(Kutipan wawancara dengan Kel. Bapak Ruslan yang bekerja sebagai seorang petani dan ibu Nenci Sahusiwa sebagai ibu rumah tangga)

Tindakan atau upaya yang terakhir adalah membangun kerjasama yang baik dengan guru Anak Usia Dini. Penelitian yang dilakukan oleh Khadijah mengatakan bahwa kerjasama orang tua dengan guru merupakan kunci keberhasilan belajar anak di rumah (Khadijah \& Gusman, 2020). Setidaknya ada tiga model kerjasama yang dilakukan di TK Rusyda yaitu: model satu arah, dua arah dan multi arah. Hal senada juga dikatakan oleh Julinda Siregar dalam penelitiannya menyimpulkan bahwa orang tua harus pro aktif dalam membangun komunikasi dengan guru terkait materi dan strategi pembelajaran sehingga anak betah belajar dari rumah (Siregar \& Murniarti, 2020).

Sinergitas antara guru dengan orang tua menjadi salah satu keberhasilan pembelajaran anak. Orang tua harus merubah paradigma selama ini yang secara tidak langsung dalam tindakannya menyerahkan pendidikan anak seutuhnya kepada sekolah. Saat ini, orang tua harus belajar dan terus belajar untuk terlibat dalam pembelajaran anak terlebih di masa pandemi saat ini (Irma et al., 2019). Salah satu kerjasama yang harus dibangun dengan guru adalah komunikasi yang baik. Alangkah lebih baik jika orang tua bertanya dan membangun komunikasi yang baik dengan guru ketika ada permasalahan belajar anak(Siregar \& Murniarti, 2020). Itu akan memberikan jalan keluar terbaik dibanding sikap orang tua yang gegabah dan terkesan menyalahkan pihak lain. Demikian juga dengan guru untuk selalu mengedepankan komunikasi dengan keluarga dalam mengatasi permasalahan belajar anak sehingga anak tidak menjadi korban.

Orang tua yang sibuk dengan pekerjaan memiliki waktu yang tidak banyak bersama anak. Tentunya orang tua hanya bisa memperhatikan atau mendampingi anak belajar setelah pulang dari tempat kerja. Terkadang rasa capek dari tempat kerja juga sangat kurang mendukung untuk mendampingi anak dalam belajar, sebab itu salah satu tindakan orang tua ditengah kesibukannya adalah meminta bantuan guru untuk datang ke rumah mendampingi anak belajar. Hal ini bertujuan agar hak belajar anak tetap terpenuhi di tengah wabag virus corona. Berikut ini adalah bebebrapa kutipan wawancara penulis dengan orang tua anak usia dini sebagai informan penelitian.

...Meminta tolong kepada guru, untuk selalu melakukan pendampingan, dan berharap agar proses belajar mengajar bisa berjalan normal kembali...(Kutipan wawancara dengan keluarga Bapak Samuel dan ibu Jolanda)

... Kami selaku orang tua, selalu mengikuti apa yang guru mau, bagi yang sekolah di SD, dan SMP, kami mengupayakn agar anak dapat melakukan pembelajaran online, dengan menyiapkan $H P$, sedangkan bagi anak kami yang di paud, kami sering melakukan komunikasi dengan guru, karena kami selaku orang tua tidak bisa menggantikan peran guru...(Kutipan wawancara keluarga Bapak Daud dan Ibu Orpa)

... Meminta tolong kepadai guru untuk melakukan pendampingan. Walau di PAUD Melissa melakukan pembelajaran tatap muka 1 minggu 2 kali, tapi kami selaku orang tua, punya keinginan untuk sekolah normal kembali...(Kutipan wawancara dengan keluarga bapak Harold dan Ibu Noni) 
... Meminta tolong kepada guru untuk hadir di rumah, karena anak usia dini tidak bisa melakukan pembelajaran online tanpa pendampinga. Anak-anak akan asik bermain dengan HP jika tidak didampingi dan sebagai orang tua berharap agar proses belajar mengajar bisa berjalan normal kembali...(Kutipan wawancara dengan keluarga Bapak Galvin dan ibu Rosyan)

... Bersyukur, karna PAUD Melissa melakukan tatap muka 1 minggu 2 kali. Hanya saja kami berfikir pembelajarn seperti Ini kurang maximal karena anak-anak usia dini mereka perlu beradaptasi dengan teman-teman sebaya merekadan berharap agar proses belajar mengajar bisa berjalan normal kembali... (Kutipan wawancara dengan keluarga bapak Frits dan ibu Welna) ... Bersyukur, karna PAUD Melissa melakukan tatap muka 1 minggu 2 kali, dan pembelajaran dari rumah kerumah, sangat menolong kami selaku orang tua. Hanya pemebelajaran dari rumah kerumah kami merasa kurang maximal, karena mungkin faktor lingkungan, dan kadang saya membelikan buku untuk membantu anak sebagai pegangan di rumah...(Kutipan wawancara keluarga bapak jefri dan ibu ibu Herlin)

Segala tindakan orang tua dalam upaya mengatasi permasalahan yang telah dipaparkan, yaitu membangun kerjasama yang baik antara suami dan istri, berusaha untuk boleh saling memahami kondisi keluarga dan membangun kerjasama yang baik dengan guru, hendaknya terus dibangun dan ditingkatkan agar pelayanan pembelajaran anak selama belajar dari rumah bisa semakin optimal. Karena layanan yang baik dan optimal untuk anak dalam belajar adalah kunci utama dalam suksesnya tujuan pembelajaran (Fakhrurrazi, 2018; Gibbons, 2008).

\section{SIMPULAN}

Sebagian besar orang tua berperan untukmemperhatikan jadwal belajar, memperhatikan pelajaran, menjelaskan materi dan mendampingi anak dalam mengerjakan tugas. Adapun kendala-kendalanya adalahminimnya keahlian mengajar, sulitnya memotivasi anak, Lingkungan yangtidak kondusif, dan keterbatasan waktu. Membangun kerjasama suami istri, memahami situasi keluarga dan membangun kerjasama yang baik dengan guru menjadi solusi yang dilakukan oleh orang tua atas segala permasalahan yang dihadapi.Penelitian ini juga menunjukkan bahwa pendidikan terakhir tidak mempengaruhi orang tua untuk bisa memahami materi pelajaran AUD dan Kesibukan orang tua tidak menjadi alasan utama tidak memperhatikan pembelajaran anak di rumah, karena orang tua tetap mendampingi anak belajar setelah pulang dari tempat kerja. Penelitian ini masih terbatas pada problematika orang tua ditinjau dari pekerjaan dan latar belakang pendidikan, oleh sebab itu peneliti berharap para peneliti melanjutkan penelitian untuk meninjau problematika orang tua ditinjau dari usia dan keadaan ekonomi orang tua.

\section{UCAPAN TERIMA KASIH}

Ucapan terimakasih yang sebesar-besarnya kami sampaikan kepada PAUD Melisa yang sudah memberikan kesempatan bagi penulis untuk melakukan wawancara kepada orang tua anak usia dini. Tidak lupa juga peneliti ucapkan banyak terimakasih kepada orang tua anak usia dini yang sudah berkenan memberikan informasi yang akurat sehingga penelitian ini boleh terselesaikan dengan baik.

\section{DAFTAR PUSTAKA}

Agustien Lilawati. (2021). Peran Orang Tua dalam Mendampingi Anak di Masa Pandemi Covid-19. Jurnal Pendidikan Anak Usia Dini, 5(1), 241-256. https://doi.org/10.31004/obsesi.v5i1.541

Ambarita, J., Helwaun, H., \& Houten, L. Van. (2021). Workshop Pembuatan E-book Sebagai Bahan Ajar Elektronik Interaktif Untuk Guru Indonesia Secara Online di Tengah Covid 19 di kota Wuhan ini tidak terkecuali dengan Negara Indonesia . Banyaknya korban yang mengambil kebijakan untuk menyikapi penyebaran viru. Community 
DOI: 10.31004/obsesi.v6i3.1358

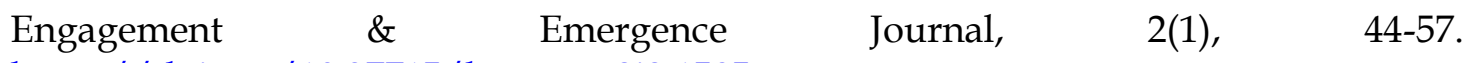
https://doi.org/10.37715/leecom.v2i2.1595

Ayuni, D., Marini, T., Fauziddin, M., \& Pahrul, Y. (2020). Kesiapan Guru TK Menghadapi Pembelajaran Daring Masa Pandemi Covid-19. Jurnal Obsesi : Jurnal Pendidikan Anak Usia Dini, 5(1), 414. https://doi.org/10.31004/obsesi.v5i1.579

Bastian, A., Suharni, \& Novitasari, Y. (2019). Permainan Tradisional Berbasis Budaya Melayu dalam Pengembangan Karakter Anak. Atṭālunā: Journal of Islamic Early Childhood Education, 2(2), 53-56. https://doi.org/10.32505/atfaluna.v2i2.974

Darmalaksana, W., Hambali, R. Y. A., Masrur, A., \& Muhlas. (2020). Analisis Pembelajaran Online Masa WFH Pandemic Covid-19 sebagai Tantangan Pemimpin Digital Abad 21. Karya Tulis Ilmiah (KTI) Masa Work From Home (WFH) Covid-19 UIN Sunan Gunung Djati Bandung Tahun 2020, 1(1), 1-12.

Darmayanti, T., Yudhi Setiani, M., \& Oetojo, B. (2007). E-Learning Pada Pendidikan Jarak Jauh: Konsep Yang Mengubah Metode Pembelajaran Di Perguruan Tinggi Di Indonesia. Jurnal Pendidikan Terbuka Dan Jarak Jauh, 8(2), 99-113. http://jurnal.ut.ac.id/index.php/jptji/article/view/538

Dewi, D.S., Setyani, J. \& Yulyanti, S. (2021). Cara pencegahan penyebaran covid-19. Proceding Seminar Nasional, 1(1), 111-116.

Dewi, I., \& Suryana, D. (2020). Analisis Evaluasi Kinerja Pendidik Pendidikan Anak Usia Dini di PAUD Al Azhar Bukittinggi. Jurnal Obsesi : Jurnal Pendidikan Anak Usia Dini, 4(2), 1051. https:// doi.org/10.31004/obsesi.v4i2.465

Emda, A. (2018). Kedudukan motivasi belajar siswa dalam pembelajaran. Lantanida Journal, 5(2), 172. https:// doi.org/10.22373/li.v5i2.2838

Fakhrurrazi. (2018). Hakikat Pembelajaran Yang Efektif. At-Tafkir, 11(1), 85. https://doi.org/10.32505/at.v11i1.529

Fauzi, A. (2020). Penanggulangan pergaulan bebas remaja melalui pendekatan pendidikan spiritual. BIDAYAH, 11(1), 63-86. https://doi.org/10.47498/bidayah.v11i1.313

Furqon Arbianto, U., Widiyanti, W., \& Nurhadi, D. (2019). Kesiapan Technological, Pedagogical And Content Knowledge (Tpack) Calon Guru Bidang Teknik di Universitas Negeri Malang. Jurnal Teknik Mesin Dan Pembelajaran, 1(2), 1. https://doi.org/10.17977/um054v1i2p1-9

Gibbons, P. \&. (2008). Efektivitas Pembelajaran. Jurnal Pendidikan Usia Dini, 9(1), 8. https:// doi.org/10.21009/JPUD.091

Ginanjar, M. H. (2017). Keseimbangan Peran Orang Tua Dalam Pembentukan Karakter Anak. Edukasi Islami: Jurnal Pendidikan Islam, 2(03), 230-242. https:// doi.org/10.30868/ei.v2i03.27

Hatimah, I. (2016). Keterlibatan keluarga dalam kegiatan di sekolah dalam perspektif kemitraan. PEDAGOGIA, 290-297. https://doi.org/10.17509/pedagogia.v14i2.3878

Heriyanto, H. (2018). Thematic Analysis sebagai Metode Menganalisa Data untuk Penelitian Kualitatif. Anuva, 2(3), 317. https:// doi.org/10.14710/anuva.2.3.317-324

Ilpaj, S. M., \& Nurwati, N. (2020). Analisis Pengaruh Tingkat Kematian Akibat Covid-19. Jurnal Pekerjaan Sosial, 3(1), 16-28. https:// doi.org/10.24198/focus.v3i1.28123

Irma, C. N., Nisa, K., \& Sururiyah, S. K. (2019). Keterlibatan Orang Tua dalam Pendidikan Anak Usia Dini di TK Masyithoh 1 Purworejo. Jurnal Obsesi : Jurnal Pendidikan Anak Usia Dini, 3(1), 214. https://doi.org/10.31004/obsesi.v3i1.152

Jailani, M. S. (2014). Teori Pendidikan Keluarga dan Tanggung Jawab Orang Tua dalam Pendidikan Anak Usia Dini. Nadwa, 245. https://doi.org/10.21580/nw.2014.8.2.580

Jalli, N. (2020). Kesenjangan akses internet di Asia Tenggara jadi tantangan bagi pengajaran online akibat pandemi COVID-19. The Conversation. 
Jumrawarsi, \& Suhaili, N. (2020). Peran Seorang Guru Dalam Menciptakan Lingkungan Belajar Yang Kondusif. Ensiklopedia Education Review, 2(3), 50-54. https:// doi.org/10.33559/eer.v2i3.628

Kemendikbud. (2019). Surat Edaran Nomor $14 \quad 2019.22$. https:// www.kemdikbud.go.id/main/blog/2019/12/surat-edaran-nomor-14-tahun2019-tentang-penyederhaan-rencana-pelaksanaan-pembelajaran

Kemendikbud. (2020a). Pelaksanaan kebijakan pendidikan dalam masa darurat penyebaran $\begin{array}{lllllll}\text { co ro naviru } & \mathrm{d} / \text { sease } & \text { (covid- } & 1 & 9 \text { ). }\end{array}$ https:// www.kemdikbud.go.id/main/blog/2020/03/mendikbud-terbitkan-setentang-pelaksanaan-pendidikan-dalam-masa-darurat-covid19

Kemendikbud, B. K. dan H. M. S. (2020b). Orang Tua Memegang Peranan Penting dalam Pelaksanaan Belajar dari Rumah. SIARAN PERS Nomor: 147/Sipres/A6/VI/2020. https:/ / bersamahadapikorona.kemdikbud.go.id/24-juni-2020-kemendikbud-orangtua-memegang-peranan-penting-dalam-pelaksanaan-belajar-darirumah/\#: :text=Selain secara daring $\% 2 \mathrm{C}$ pada $18, \% 2 \mathrm{C}$ terluar $\% 2 \mathrm{C}$ dan tertinggal).

Khadijah, \& Gusman, M. (2020). Pola kerja sama guru dan orangtua mengelola bermain aud selama masa pandemi covid-19. Jurnal Kumara Cendekia, 8(2), 154-171. https:// doi.org/10.20961/kc.v8i2.41871

Korucu, A. T., \& Alkan, A. (2011). Differences between m-learning (mobile learning) and elearning, basic terminology and usage of m-learning in education. Procedia - Social and Behavioral Sciences, 15, 1925-1930. https://doi.org/10.1016/j.sbspro.2011.04.029

Kosim, M. (2011). Urgensi pendidikan karakter. Karsa, IXI(1), 85-92. https://doi.org/ 10.19105/ karsa.v19i1.78

Lexi, J., \& M.A., M. (2010). Metodologi Penelitian Kualitatif. In Metodologi Penelitian Kualitatif. Rake Sarasin, 54-68. https://scholar.google.com/citations?user=OB3eJYAAAAJ\&hl=en

Muis, A. (2019). Konsep dan Strategi Pembelajaran di Era Revolusi Industri 4.0 Google Books: Vol. 14 × $20 \mathrm{~cm}$. Laksana.

Nida Uliatunida. (2020). Perencanaan kurikulum untuk mencapai tujuan pendidikan. Ilmu Pendidikan Dan Dakwa, 2(1), 35-48. https:// doi.org/10.1017/CBO9781107415324.004

Noffiyanti. (2020). Mewujudkan Keharmonisan Rumah Tangga Dengan Menggunakan Konseling Keluarga, Noffiyanti. Al-Ittizaan, 3(1), 8-12. https:// doi.org/10.24014/0.8710152

Nurkolis, N., \& Muhdi, M. (2020). Keefektivan Kebijakan E-Learning berbasis Sosial Media pada PAUD di Masa Pandemi Covid-19. Jurnal Obsesi : Jurnal Pendidikan Anak Usia Dini, 5(1), 212. https:// doi.org/10.31004/obsesi.v5i1.535

Nurul Fadlilah, A. (2021). Jurnal Obsesi: Jurnal Pendidikan Anak Usia Dini Strategi Menghidupkan Motivasi Belajar Anak Usia Dini Selama Pandemi COVID-19 melalui Publikasi. Jurnal Obsesi: Jurnal Pendidikan Anak Usia Dini, 5(1), 373-384. https://doi.org/10.31004/obsesi.v5i1.548

Pakpahan, R., \& Fitriani, Y. (2020). Analisa Pemafaatan Teknologi Informasi Dalam Pemeblajaran Jarak Jauh Di Tengah Pandemi Virus Corona Covid-19. JISAMAR (Journal of Information System, Applied, Management, Accounting and Researh), 4(2), 30-36.

Pininta, A. K. (2020). Survei UNICEF: 66 Persen Siswa Mengaku Tak Nyaman Belajar di Rumah. Kompas.Com. https://edukasi.kompas.com/

Pujiasih, E., \& Bantul, S. M. A. N. (2020). Membangun Generasi Emas Dengan Variasi Pembelajaran Online Di Masa Pandemi Covid-19 Building a Golden Generation By Applying Various Online Learning in the Pandemic of Covid-19. Jurnal Karya Ilmiah Guru, 5(1), 42-48. https://doi.org/10.51169/ideguru.v5i1.136

Purwanto, A., Pramono, R., Asbari, M., Santoso, P. B., Wijayanti, L. M., Hyun, C. C., \& Putri, R. S. (2017). Studi Eksploratif Dampak Pandemi COVID-19 Terhadap Proses 
Pembelajaran Online di Sekolah Dasar. EduPsyCouns: Journal of Education, Psychology and Counseling, 2(1), 165-170.

Purwasih, R., Aripin, U., \& ... (2020). Pelatihan Pembelajaran E-Learning Berbasis Website Bagi Guru Smp Melalui Pendekatan Revolusi 4.0 Di Era Covid-19. Prosiding Seminar Nasional Rekarta 2020, 6-7. https:// doi.org/10.31932/jpmk.v4i1.1060

Radarbekasi.id. (2020). Mengajar Siswa PAUD Lebih Sulit. Radarbekasi.Id. https://radarbekasi.id/2020/10/05/mengajar-siswa-paud-lebih-sulit/

Rahmatullah, A. S. (2017). Pendidikan Keluarga Seimbang yang Melekat Sebagai Basis yang Mencerahkan Anak di Era Digital. Cendekia: Journal of Education and Society, 15(2), 211. https:// doi.org/10.21154/cendekia.v15i2.1144

Ramadhani, Y. P., Guru, P., Dasar, S., Kristen, U., Wacana, S., \& Sosial, K. (2020). Model Permainan Tradisional untuk Meningkatkan Keterampilan Sosial Anak Sekolah Dasar. Jurnal Pendidikan Tambusai, 4(1), 248-255.

Sadikin, A., \& Hamidah, A. (2020). Pembelajaran Daring di Tengah Wabah Covid-19. BIODIK, 6(2), 109-119. https:// doi.org/10.22437/bio.v6i2.9759

Samsinar. (2019). Pola komunikasi keluarga dalam perspektif islam. 53(9), 1689-1699. https://doi.org/10.35673/ajdsk.v5i1.567

Siregar, J., \& Murniarti, E. (2020). Kerjasama Guru dan Orang Tua dalam Mengelola Strategi Pembelajaran Home Learning Masa Pandemi Covid-19 di PAUD Kasih Efrata Jatiasih Bekasi. Jurnal Dinamika Pendidikan, 13(3), 245-254. https://doi.org/10.33541/jdp.v12i3.1295

Suadnyana, I. B. P. E. (2018). Kajian Nilai Pendidikan Agama Hindu Dalam Konsep Manyama Braya. Jurnal PASUPATI, 5(1), 48. https:// doi.org/10.37428/pspt.v5i1.128

Sulata, M. A., \& Hakim, A. A. (2020). Gambaran Perkuliahan Daring Mahasiswa Ilmu Keolahragaan Unesa Di Masa Pandemi Covid-19. Jurnal Kesehatan Olahraga, 8, 147156.

Supsiloani, S. S., Puspitawati, P. P., \& Hasanah, N. (2016). Eksistensi Taman Penitipan Anak dan Manfaatnya bagi Ibu Rumah Tangga yang Bekerja (Studi Kasus di TPA Dharma Asih Kota Medan). Jupiis: Jurnal Pendidikan Ilmu-Ilmu Sosial, 7(2), 119. https:// doi.org/10.24114/jupiis.v7i2.3117

Wardani, A., \& Ayriza, Y. (2020). Analisis Kendala Orang Tua dalam Mendampingi Anak Belajar di Rumah Pada Masa Pandemi Covid-19. Jurnal Obsesi : Jurnal Pendidikan Anak Usia Dini, 5(1), 772. https:// doi.org/10.31004/obsesi.v5i1.705

Wicaksana, E. (2020). Efektifitas pembelajaran menggunakan moodle terhadap motivasi dan minat bakat peserta didik di tengah pandemi covid -19. EduTeach : Jurnal Edukasi Dan Teknologi Pembelajaran, 1(2), 117-124. https://doi.org/10.37859/eduteach.v1i2.1937 